日臨外会誌 $60(6), 1643-1646,1999$

症例

胆石症の精查中に発見された膵の悪性 solid cystic tumor の 1 例

名古屋共立病輐外科

内藤明広川原勝彦岩田宏田那村收

症例は 49 歳, 女性で糖尿病のため食事療法中である.18 年前胆石症による急性䐙炎の 治療歷があり，外来で施行した腹部 ultrasonography（以下 US）で蕠頭部腫場を指摘さ れた. 1997 年 11 月 20 日に手術施行, 術中迅速凍結病理組織診断で悪性 carcinoid 腫瘍を 疑われ、粠頭十二指腸切除術および胆襄摘出術施行した. 通常の組暂学的および免疫 学的検索により，莝の悪性 solid cystic tumor 之診断された，術後経過は良好であった. 䐙の solid cystic tumor は若年女性の好発し，多くは予後良好であるが，時に悪性で局所 再発や遠隔転移を来す，自験例について文献的考察を加元報告する。

索引用語：䐙腫瘍, solid cystic tumor, 胆石症

緒 言

䐙の solid cystic tumor は, 若年, 女性に好発する比 較的稀で予後良好とされる腫場である. 今回, 胆石症 の精查中に偶然発見され，組䅧学的に瑟性と猃断され た苏原発 solid cystic tumorを経験したので考察を加 え報告する。

患者：49 歳，女性.

$$
\text { 症例 }
$$

家族歴：特記すべき事なし。

既往歴：19 歳時虫垂切除術, 31 歳時胆石蓃炎(保存 療法)，糖尿病（食事療法）。

主訴：胆石症および外来で偶然発見された豚頭部腫 瘤の精査, 加療.

現病歴：1997年 4 月 14 日，口渴を主訴に当院内科 受診. 糖尿病と診断され, 内科通院加療となる（食事 療法). 6 月 12 日, 約 18 年前に胆石脺炎の既往歴のあ ることを本人より聴取し、腹部US施行したところ, 胆

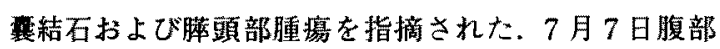
$\mathrm{CT}$ 施行. 9 月 10 日 ERCP 施行. 11 月 5 日胆石および 䐙頚部腫湯の精查, 加療目的にて入院となった。

入院時身体所見：身長 $148.5 \mathrm{~cm}$, 体重 $59.5 \mathrm{~kg}$ と中 等度肥満. 栄養状態良好, 血圧 $120 / 66 \mathrm{mmHg}$, 結膜に 負血，黄㾝なし，鎖骨上裔，腋窝りンバ節触知せず。 心肺聴診上巽常所見なし、腹部に腫㿔は触知せず，そ の他理学的所見も異常なし. 神経学的にも異常所見な

1998 年 6 月 23 日受付 1999 年 3 月 30 日採用
L.

検查成績：WBC $7,500 / \mu 1, \mathrm{RBC} 429 \times 10^{4} / \mu \mathrm{l}, \mathrm{Hb} 11.3$ $\mathrm{g} / \mathrm{dl}$, Ht $34.8 \%$, Plt $27.3 \times 10^{4} / \mu \mathrm{l}$, PT $109 \%$, APTT 23.5 sec, TP $6.7 \mathrm{~g} / \mathrm{dl}$, BUN $7.7 \mathrm{mg} / \mathrm{dl}$, Creatinine $0.54 \mathrm{mg} /$ $\mathrm{dl}, \mathrm{Na} 136 \mathrm{mEq} / \mathrm{l}, \mathrm{K} 4.0 \mathrm{mEq} / \mathrm{l}, \mathrm{Cl} 103.4 \mathrm{mEq} / \mathrm{l}, \mathrm{Ca}$ $4.03 \mathrm{mEq} / l, \mathrm{ALP} 101 \mathrm{IU} / l$, GOT $13 \mathrm{IU} / l$, GPT $8 \mathrm{IU} / l$, LDH $245 \mathrm{IU} / l$, Amylase $79 \mathrm{IU} / l$, 血糖 $191 \mathrm{mg} / \mathrm{dl}$ で末 梢血血算, 生化学検查とも特に翼常を認めなかった。 術前腫瘍マーカーは測定していない.

腹部 US 所見（図 $1 \mathrm{a}, \mathrm{b}$ )：膵頭部に境界比較的明瞭 な長径䄪 $2.5 \mathrm{~cm}$, 辺縁平滑, 内部 echo pや低く不均一 な充実性腫瘤を認めた，胆㖶内には音響除影を伴う結 石像を認めた。

腹部 CT 所見（図 $\mathbf{2} \mathbf{a}, \mathbf{b})$ ：腹部 CTでは単純で isodensity, 造影では low となる境界比較的明暸な径

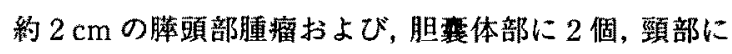
1 個の結石像を認めた。

ERCP 所見（図 $3 \mathbf{a}, \mathbf{b})$ ：ERCP では主满管の走行巽 常, 拡張, 浸閏所見等は認められず，胆裹は顠部の結 石嵌頖による描出不良所見を呈した。

以上の所見より, 胆豪結石, 苏頭部の solid cystic tumorを最も疑い, 手術適応と判断した。

手術： 11 月 20 日手術施行. 開腹時, 腹水おうざ腹腔 内播種病巣等はなく，䐙前面に達したところ，䑏頭部 の腹側寄りに腫瘤を触知した.肉眼的には被膜を有し， 周囲組織への明らかな浸潤所見は認められず，リンパ 節腫大も無かったため，まず䐙頭部の径 $2.0 \mathrm{~cm}$ の腫瘤 


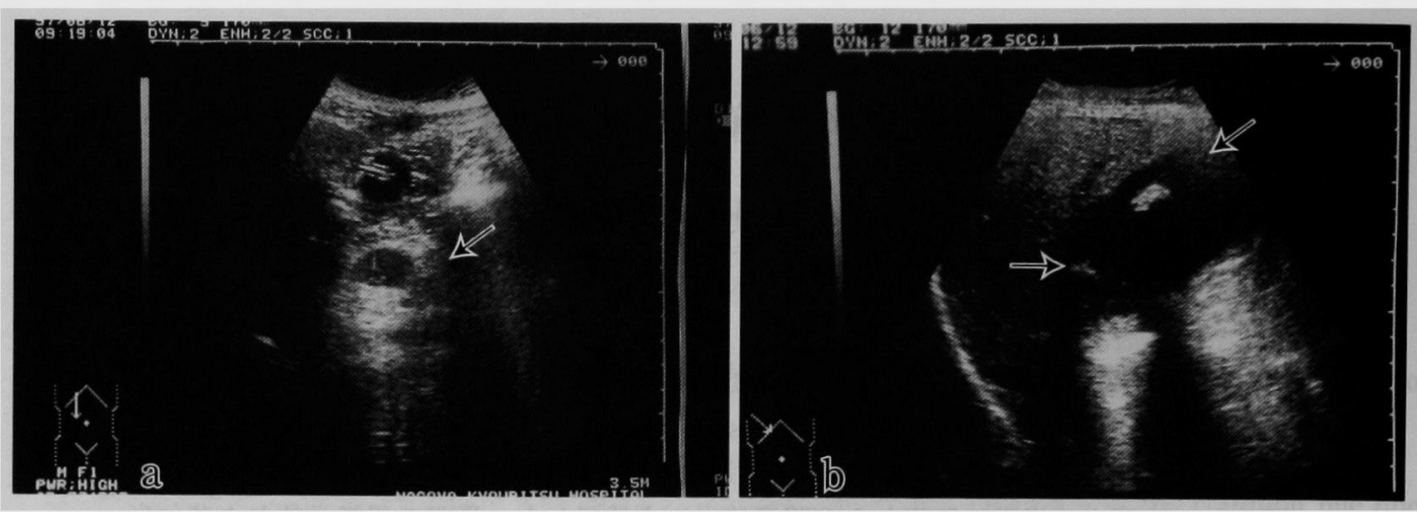

図 1 腹部 US (1997.6. 12)：腪頭部に長径 $2.5 \mathrm{~cm}$, 辺縁平滑, 内部 echoはやや低く

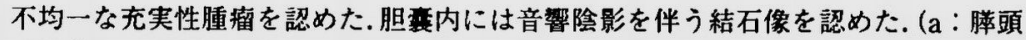
部腫瘤, $b$ : 胆要内結石)
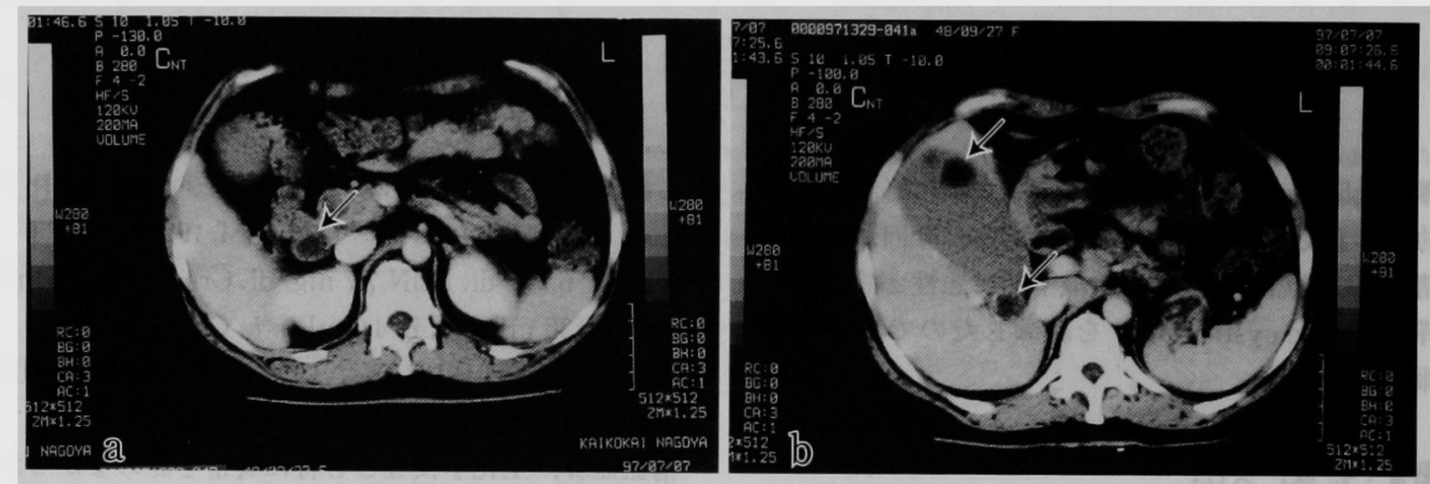

図 2 腹部 CT（1997.7.7）：造影 CT で low となる茦頭部腫瘤および，胆荽体部に 2

個, 頚部に 1 個の結石影を認めた. (a：莝頭部腫瘤, $\mathrm{b}$ ：胆震内結石)

を核出した．腫瘤の術中迅速凍結病理組織診で㬸実質 組織への浸潤所見が認められ，悪性腫瘍（malignant carcinoid tumor）を強く疑われたため，膵頭十二指腸 切除術 $+D_{1}$ 郭清術を施行した. 消化管の再建は今永法 変法（膵胃吻合）で施行した．肝門部胆管空腸吻合の ドレーンは経皮経肝的に以外へ誘導，荤管ドレナージ は胃内の lost tube とした. 胆裹は急性胆粪炎と思われ る著明な炎症所見を認め,内部にコレステロール結石 が 3 個存在した。

切除標本 (図 $4 a, b)$ ：膵頭部腫瘤は肉眼的には被膜 を形成し，内部は一部表胞状の径 $2.0 \mathrm{~cm}$ の実質性腫瘍 であった，胆基は著明な炎症所見を示し，内部に計 3 個の結石が存在した.

病理組織所見（図 5)：HE 染色では，大小不同の目 立つ好酸性の異型細胞が莝実質へ浸潤している所見を 認めた (medullary type, INF $\alpha, \mathrm{ly}_{0}, \mathrm{v}_{0}, \mathrm{ne}_{1,}, \operatorname{mpd}(-)$,
So, $\mathrm{rp}_{0}, \mathrm{ch}_{0}, \mathrm{du}_{0}, \mathrm{pv}_{0}, \mathrm{pw}(-)$, ew $\left.(-)\right)$. 所属リンパ節 転移は無かったが，䐙実質への浸潤所見より悪性と判 断した. 㭗腫瘍の免疫組織染色では, Vimentin $(++)$, Chromogranin $\mathrm{A}(+), \alpha_{1}$-antitrypsin $(+), \operatorname{NSE}(-)$, EMA (-), Glimerius (+), $\operatorname{CEA}(-), \operatorname{Leu} 7(-)$ で, HEの所見と合わせ, 日本腪臓学会編胼癌取扱い規 約の中の「分化方向の不明な上皮性腫瘍」の範嚋に入 る羘原発悪性 solid cystic tumor と診断した. 胆变は高 度な急性炎症所見を呈していた。

術後経過：術後経過は良好で, 腹腔内感染, 綎合不 全等の合併症もなく，12月1日より経口搨取を再開. 12 月 12 日, 胆管空腸吻合部の drainage tube を抜去. 12 月 15 日, $\mathrm{CV}$ ルート抜去. 12 月 20 日退院, 外来通 院となった，術後化学療法は行っていない。

\section{考察}

䐙原発 solid cystic tumor（以下 SCT）は若年，女性 

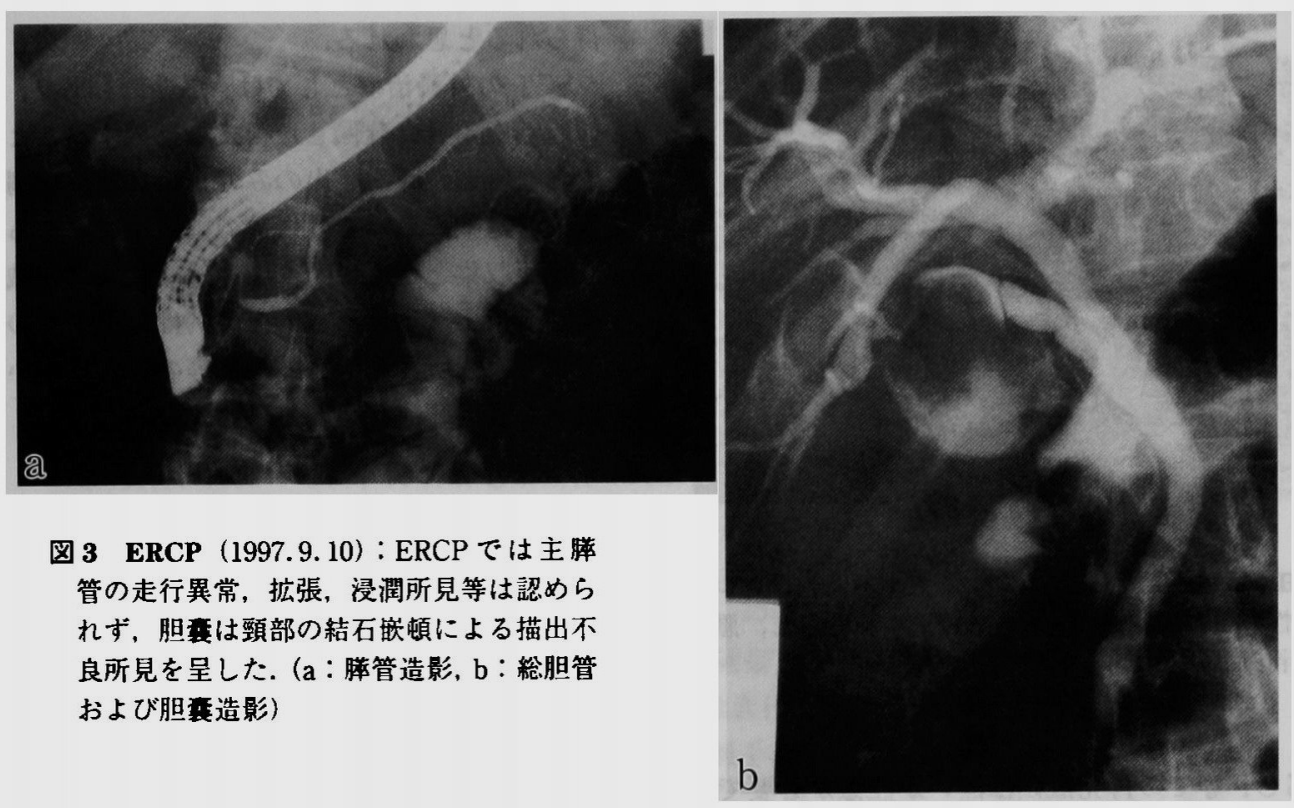

图3ERCP (1997.9.10)：ERCPでは主粹 管の走行異常, 拡張, 浸阚所見等は認めら れず，胆重は䫫部の結石嵌頓による描出不 良所見を呈した（a：羘管造影, b：総胆管 および胆靖造影)

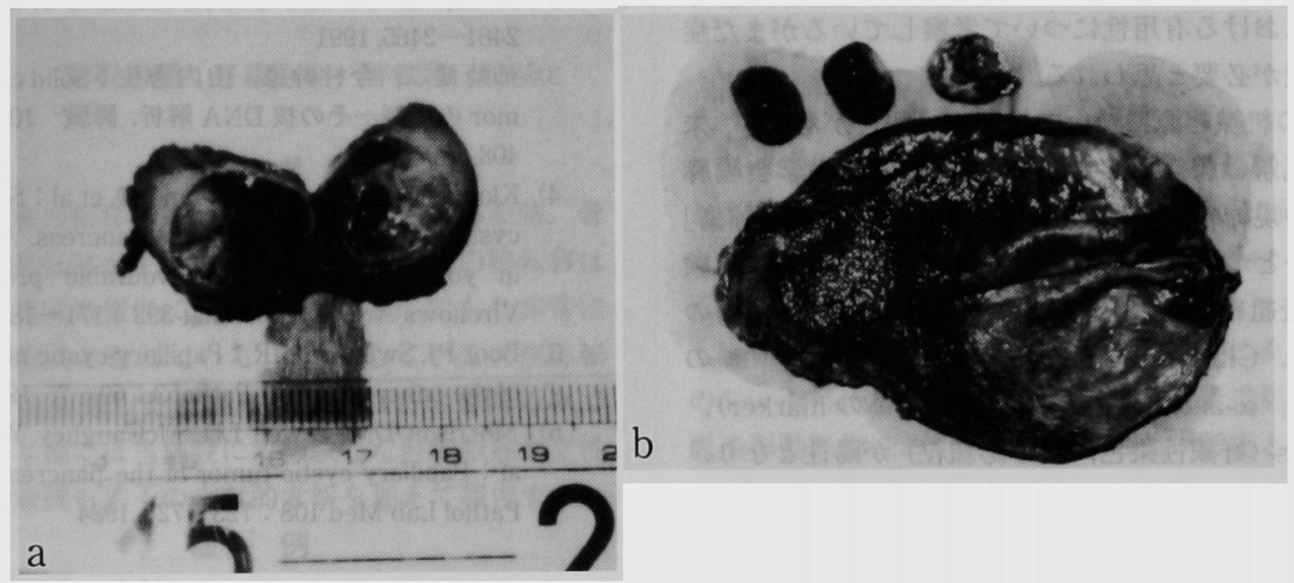

図 4 切除標本 : 羘頭部の腫瘤は被膜形成を有し,内部は一部竡胞状の径 $2.0 \mathrm{~cm}$ の実 質性腫瘍であった. 胆衰は著明な炎症所見を示し, 内部に計 3 個の結石が存在した。 ( $\mathrm{a}$ : 羘頭部腫瘤の割面, $\mathrm{b} ：$ 胆軎および胆妾結石)

に好発する比較的稀で予後良好とされる腫演で，沖野 らが本疾患 173 例をまとめて報告している1．SCTは 腹痛・腹部腫瘤で発見されることが多く，発見時には $10 \mathrm{~cm}$ を越える巨大腫瘤であることも少なくない，検 診や他疾患での精査中に発見されたものは $17 \%$ と報 告している. 若年の女性に圧倒的に多く, 予後は一般 に良好とされているが、肝転移, 腹膜播種による死亡 症例もある. 悪性化の所見としては肉眼的な周囲臓器 浸潤, リンパ節転移, 遠隔転移, 局所再発と, 組織学
的な被膜・周囲臓器浸潤，血管侵襲などがあげられ る゙・.最近になり症例の蓄積により悪性例も必ずしも 少なくないことが知られ始めているが，良悪性の爁別 が必ずしも容易でないこともある．自験例は図 5 の如 く，所属リンパ節，遠隔転移は無かったが，膵実質へ の浸閏所見を認めたため，悪性と判断した”。術後の血 清 CEA 值は 1998 年 1 月 9 日 $5.2 \mathrm{ng} / \mathrm{ml}, 4$ 月 24 日 9.6 $\mathrm{ng} / \mathrm{ml} .7$ 月 10 日 $9.2 \mathrm{ng} / \mathrm{ml}, 10$ 月2 日 $7.6 \mathrm{ng} \mathrm{ml}$ と 正 常值 $(5.0 \mathrm{mg} / \mathrm{ml}$ 以下) をやや上回る值で変動してお 


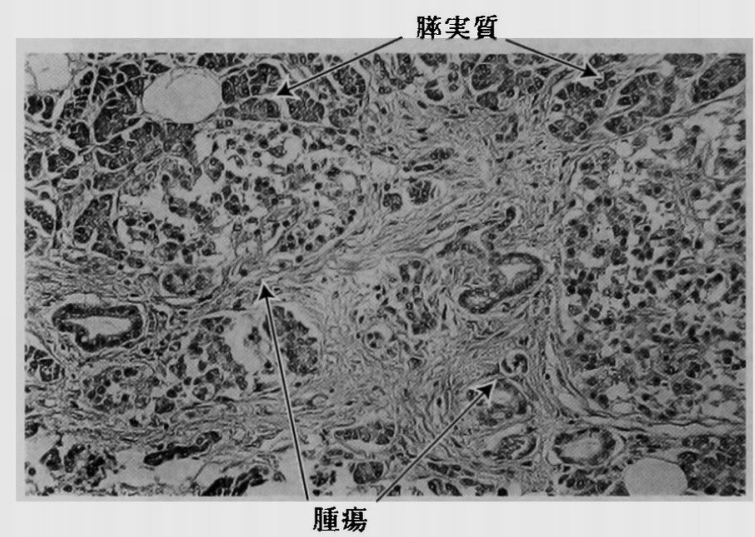

图 5 HE 染色所見：HE 染色では, 大小不同の目立つ 好酸性の異型細胞が腪実質への浸潤所見を示し, 悪 性と判断された。

り，腹部 CT 等での再発徴候は無いが注意が必要であ る.また柿崎らがSCT の核 DNA を解析し，その悪性 度判定における有用性について考察しているがまだ症 例の蓄積が必要と思われる

SCT の組織起源については諸家の報告があるが, 未

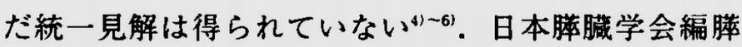
癌取扱い規約の中では「分化方向の不明な上皮性腫瘍」 の中のひとつの独立単位として分類されている．自験 例の免疫組織染色でも,Vimentin（非上皮性腫瘍の marker)，Chromographin A（神経内分泌腫瘍の marker)， $\alpha_{1}$-antitrypsin（荤腺房性腫澔の marker), Glimerius（好銀性染色，内分泌顆粒）が陽性となり， 分化方向不明な腫富という考えを支持する結果であっ た. 今後の分子生物学的な研究によりさらなる知見が
得られると思われる.

SCT の外科治療としては, 要性例もあり, 腫瘍から の断端を十分に確保した術式を選択することも時に必 要となるが, 腫瘤核出のみで良い良性の症例もあり， 術式の選択においては術前の画像検査によるより詳細 な情報収集とともに, 術中迅速凍結病理組織診断の活 用が有用と考えられる.自験例は手術からの経過がま だ短く，局所再発，遠隔転移等の有無について今後の 慎重な経過観察が必要と思われた。

\section{結語}

胆石症の精査中に偶然発見され，組織学的に悪性と 診断された羘原発 solid cystic tumor 経験したので 考察を加え報告した。

\section{文献}

1）沖野秀宣, 上田祐滋, 豊田清一：膵 solid and cystic tumor $の 1$ 例. 日臨外医会誌 $58: 196-201$. 1997

2）浅利 靖, 島津盛一, 西村博行他：巨大な莿 solid and cystic tumor $の 1$ 症例. 日消外会誌 24 ： 2461-2465. 1991

3）柿崎健二, 今村幹雄, 山内秀生 : Solid cystic tumor の 1 例一その核 DNA 解析. 羘臟 $10: 404-$ 408, 1995

4) Kloppel G, Morohoshi T. John HD, et al : Solid and cystic acinar cell tumor of the pancreas. A tumor in young woman with favourable prognosis. Virchows Arch Pathol Anat 392: 171-183, 1981

5) Boor PJ. Swanson MR : Papillary-cystic neoplasm of the pancreas. Am J Pathol $3: 69-75,1979$

6) Morrison DM. Jewell LD. McCaughey WTE, et al : Papillary cystic tumor of the pancreas. Arch Pathol Lab Med 108: 723-727, 1984

\title{
A CASE OF MALIGNANT SOLID CYSTIC TUMOR OF PANCREAS FOUND BY DETAILED EXAMINATION OF CHOLELITHIASIS
}

\author{
Akihiro NAITO. Katsuhiko KAWAHARA. Hiroshi IWATA and Osamu TANAMURA \\ Department of Surgery, Nagoya Kyoritsu Hospital
}

A 49-year-old woman under dietary therapy for diabetes mellitus on an ambulant basis was pointed out to have a tumor of the pancreatic head by abdominal ultrasonography. She was admitted to the hospital for operation. There was a previous history of acute pancreatitis due to cholelithiasis 18 years before admission. Intraoperative frozen section histology offerred a suspicion of malignant carcinoid tumor. Pancreatic duodenectomy and cholecystectomy were performed. Conventional histopathological and immunohistochemical examinations revealed malignant solid cystic tumor of the pancreas. After the operation the patient recovered uneventfully. Solid cystic tumor of the pancreas is a rare type of pancreatic tumor and is common in young women. It is usually benign, but sometimes malignant with local recurrence and distant metastasis. We report our case together with a review of the literature. 